\title{
De Clérambault Syndrome: A case presentation
}

Clara de Oliveira Lapa1, Lucas Spanemberg²

1 - Universidade Federal do Rio Grande do Sul

2- Pontifícia Universidade Católica do Rio Grande do Sul

Objective: To describe a case of de Clérambault syndrome

\section{Background: De Clérambault syndrome} refers to a deliriant conviction of love that generally involves a woman with an older man of higher social position. This syndrome is estimated to affect 15:100.000 patients.

\section{Case report: A 53-year-old married} woman sought help at the request of her family because of her desire to divorce. Eight years ago, she went to an appointment and at the first moment she saw the professional, she knew that he was in love with her. Over 8 years, the patient says that he followed her without being seen and secretly sent videos with love connotations to her cell phone.
Recently, the patient went to a new appointment, and this time, she felt that the professional would like her to divorce. When questioned, the patient said that he did not say anything because he knew that she was married, but that they have a different way of communicating.

After eliminating possible organic diseases and with 8 weeks of treatment with Risperidone ( $1 \mathrm{mg})$, the patient has shown partial improvement of the delusions. She no longer thinks of leaving home, and she thinks that the professional has stopped communicating, although he still loves her.

Conclusion: Correct adherence to treatment can cause complete remission of symptoms in some patients. Publication of more cases of this syndrome is essential to improve the treatment and management of these patients.

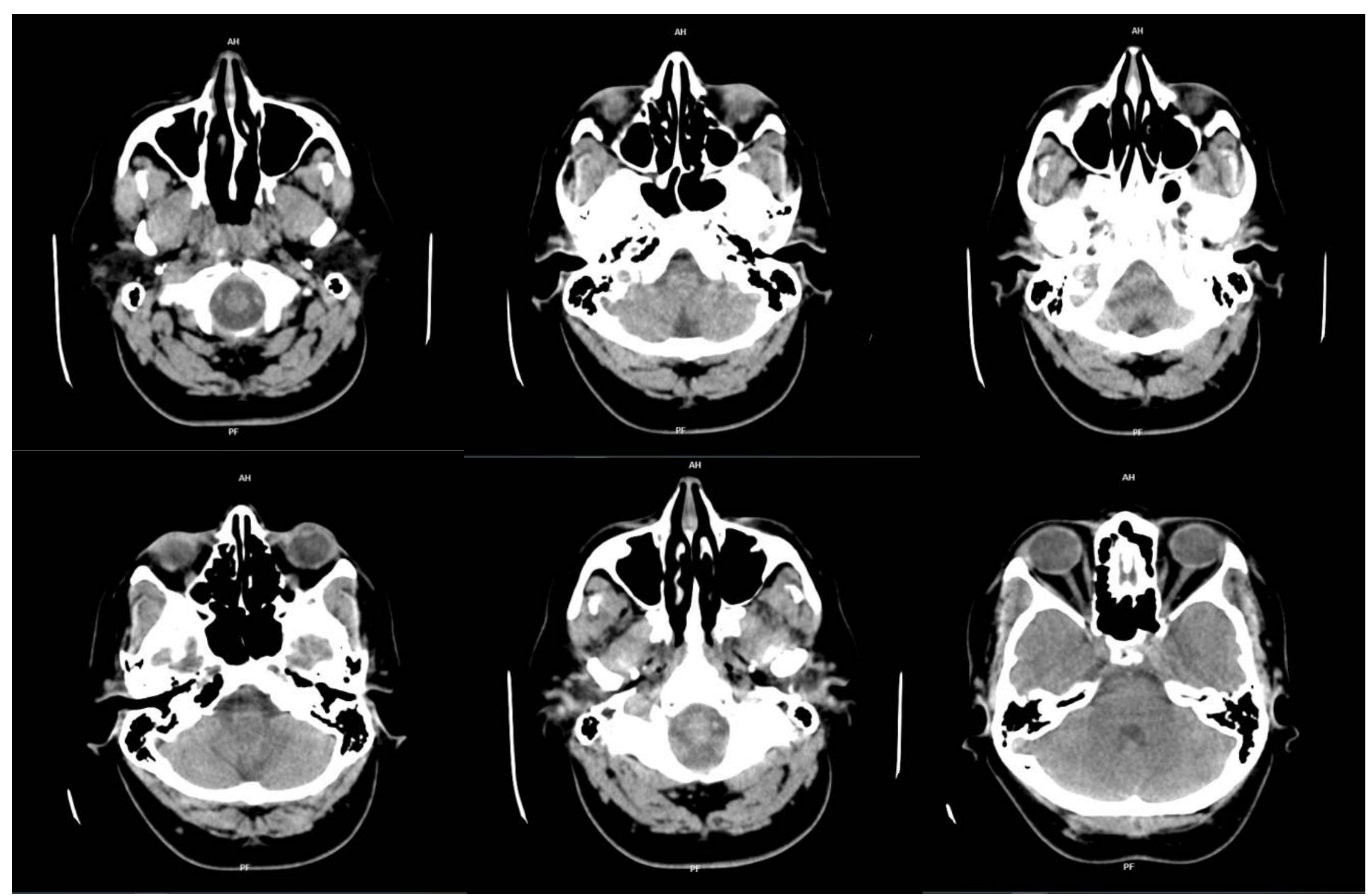

REFERENCES

(No CT evidences of acute pathology)

1. RASKIN, D. E. \& SULLIVAN, K. E. Erotomania. American Journal of Psychiatry 131, 1033-1035 (1974).

2. Mellsop, P. G. Brief Reports De ClÃ @ rambault 's Syndromeâ €” A Nosological Entity ? British Journal Of Psychiatry 90-93 (1985).

3. Calil, L. C. \& Terra, J. R. The De Clèrambault's syndrome: a bibliographic revision. Brazilian Journal of Psychiatry 27, 152-156 (2005)

4. Kennedy, N., McDonough, M., Kelly, B. \& Berrios, G. E. Erotomania revisited: clinical course and treatment. Compr Psychiatry 43, 1-6 (2002).

5. Rudden, M., Sweeney, J. \& Frances, A. Diagnosis and clinical course of erotomanic and other delusional patients. Am J Psychiatry 147, 625-628 (1990).16. Sampaio, T. de M., Andrade, A. G. de \& Baltieri, D. A. De Clérambault's syndrome: diagnostic and therapeutic challenge. Revista de Psiquiatria do Rio Grande do Sul 29, 212-218 (2007) 